\section{Regards sur l'économie allemande}

Bulletin économique du CIRAC

$100 \mid 2011$

Varia

\title{
Crise de 2008/09
}

PLUMPE W., Wirtschaftskrisen. Geschichte und Gegenwart / THEURL T. (ed), Wirtschaftspolitische Konsequenzen der Finanz- und Wirtschaftskrise / STEINBACH A., STEINBERG P., Nach der Krise ist vor der Krise. Haben wir die richtigen Lehren gezogen und was bleibt zu tun?

\section{OpenEdition}

Journals

Édition électronique

URL : http://journals.openedition.org/rea/4234

DOI : $10.4000 /$ rea. 4234

ISBN : 978-2-8218-0894-2

ISSN : 1965-0787

Éditeur

CIRAC

Édition imprimée

Date de publication : 17 mars 2011

ISSN : 1156-8992

Référence électronique

"Crise de 2008/09 », Regards sur l'économie allemande [En ligne], 100 | mars 2011, mis en ligne le 19 septembre 2011, consulté le 22 septembre 2020. URL : http://journals.openedition.org/rea/4234 ;

DOI : https://doi.org/10.4000/rea.4234

Ce document a été généré automatiquement le 22 septembre 2020.

(c) CIRAC 


\section{Crise de 2008/09}

PLUMPE W., Wirtschaftskrisen. Geschichte und Gegenwart / THEURL T. (ed), Wirtschaftspolitische Konsequenzen der Finanz- und Wirtschaftskrise / STEINBACH A., STEINBERG P., Nach der Krise ist vor der Krise. Haben wir die richtigen Lehren gezogen und was bleibt zu tun?

\section{RÉFÉRENCE}

PLUMPE W., Wirtschaftskrisen. Geschichte und Gegenwart, C.H.Beck Wissen, Munich, 2010, 128 p.

THEURL T. (ed), Wirtschaftspolitische Konsequenzen der Finanz- und

Wirtschaftskrise, Schriften des Vereins für Socialpolitik, vol. 329, Duncker \& Humblot, Berlin, 2010, 244 p.

STEINBACH A., STEINBERG P., Nach der Krise ist vor der Krise. Haben wir die richtigen Lehren gezogen und was bleibt zu tun? Metropolis-Verlag, Marburg, 2010, $234 \mathrm{p}$.

1 A point nommé, l'ouvrage de PLUMPE replace dans son contexte historique la récente crise de la finance mondiale et la crise de la dette qu'elle a révélée en Europe : les crises sont toujours un moment charnière dans les mutations de l'économie. Après cette 'introduction' qui s'adresse à un plus large public, le lecteur éclairé se plongera avec intérêt dans les analyses des conséquences de la crise et des leçons à en tirer pour l'action politique. Deux approches se dégagent dans ces ouvrages collectifs : celle des néo-keynesiens (STEINBACH/STEINBERG, avec une préface de P. Bofinger) et celle de l'ordo-libéralisme au cœur du modèle économique et social allemand (THEURL). (ib) 